\title{
INOVASI CHEESECAKE MENGGUNAKAN BAHAN KACANG BUNCIS SEBAGAI PENGGANTI TERIGU
}

\author{
Nonot Yuliantoro \\ Fakultas Pariwisata, Universitas Pelita Harapan, Indonesia. Email: nonot.yuliantoro@uph.edu
}

\begin{abstract}
Histori Artikel

Submitted:

11 Maret 2019

Reviewed:

18 April 2019

Accepted:

20 April 2019

Published:

15 Mei 2019

Making cheesecake using string bean is one of the latest innovations in making cheese cake that has never been seen before. Cheesecake generally use flour, this study aims at how string bean can be used as an ingredient of chiffon cheesecake by drying and processing into vegetable flour. This research was conducted to find out whether vegetable flour can affect the texture, taste, aroma and color of cheesecake. The purpose of string bean as a substitute for wheat flour is for consumption for the general public, especially for those who cannot consume gluten and make an alternative for people who do not like vegetables. In this study, we have conducted several vegetable group studies ranging from vegetable, leaf, stem, flower and fruit groups. Then found the right vegetable group to be made as a component of cheesecake, namely fruit vegetables. In addition, modifications are also made to the recipe, especially on the amount of vegetable flour. Excessive amounts will greatly affect the taste, texture, and aroma of the cheesecake. This study uses the homemade method. Homemade, which is meant by itself, is the making of using equipment that is few and can be made by anyone with the right technique.
\end{abstract}

Keywords : Cheese cake, string bean homemade.

\section{PENDAHULUAN}

Industri makanan dan minuman mengalami perkembangan berbanding lurus dengan pertambahan penduduk dikarenakan makanan dan minuman merupakan kebutuhan pokok dari setiap manusia. (Kementrian Perindustrian, 2016).

Dampak dari menggeliatnya bisnis makanan dan minuman itu, banyak restoran ataupun jasa penyedia makan dan minum yang menawarkan beragam pilihan menu makanan, tidak terkecuali pilihan menu pastry yang menyajikan hingga produk gluten free.

Gluten adalah protein yang secara alami terkandung di semua jenis serealia atau bijibijian yang tidak dapat larut dalam air dan bersifat lentur sehingga mampu membentuk kerangka yang kokoh dan makanan yang kenyal pada saat dimakan.
Gluten mengandung komponen protein yang disebut peptide, gluten dewasa ini banyak dihindari karena alasan kesehatan, terutama para penderita celiac disease yaitu alergi terhadap protein gluten yang menyebabkan gangguan kekebalan.

Dengan adanya sebagian dari masyarakat yang tidak bisa mengkonsumsi gluten maka perlu adanya alternatif produk sebagai solusi untuk menikmati produk-produk pastry yang aman dikonsumsi. Sayuran adalah salah satu alternatif yang bisa digunakan sebagai bahan pengganti tepung dalam pembuatan produk pastry. Sayuran yang dipilih yaitu sayuran dengan golongan sayuran buah yaitu kacang buncis.

Dikutip dalam buku karangan Watson (2015) kacang buncis merupakan sayuran polong semusim yang merambat. Buah, biji dan daunnya dimanfaatkan sebagai sayuran. 
Kacang buncis termasuk salah satu sayuran yang kaya akan protein dan vitamin. Banyak manfaat dari kacang buncis yang sangat baik dalam menjaga kesehatan organ tubuh. Selain enak dinikmati sebagai lalapan maupun sayuran.

Adapun tujuan penelitian yang dilakukan untuk mengetahui rasa, aroma, warna dan tekstur pada cheesecake dengan menggunakan kacang buncis yang dikeringkan sebagai pengganti tepung terigu.

Manfaat yang diperoleh dari penelitian ini adalah menghasilkan produk inovasi untuk mereka yang mengkonsusmsi makanan bebas kandungan gluten. Menurut Beranbaum (2013) cake merupakan kata dalam bahasa Inggris untuk mengatakan sejenis kue yang bahan dasar utamanya terdiri dari gula, tepung terigu, telur. Jenis cotton cake merupakan jenis kue dengan tekstur lembut seperti kapas. Adapun salah satu contoh aplikasi jenis cotton cake adalah cheesecake, kemudian cotton layer cake.

Tehnik pembuatan cotton cake hampir sama dengan chiffon cake, yaitu putih dan kuning telurnya diaduk secara dipisah Namun cotton cake memiliki tekstur yang lebih lembut dan agak lumer karena menggunakan tehnik bain marie atau steam bake, yaitu adonan dituang dalam loyang tapi direndam dalam air hangat seperti ditim, kemudian dipanggang dalam oven.

\section{LITERATURE REVIEW}

Cheesecake menurut Gisslen (2016) merupakan kue yang berasal dari Yunani yang awalnya disediakan untuk para atlit pada olimpiade pertama kali di Athena. Lalu beredar di New York oleh seorang Chef bernama Arnold Reuben. Jenis kue ini menggunakan cream cheese, susu, mentega, telur dan tepung terigu sebagai bahan dalam proses pembuatan. Cheesecake dibuat dengan menggunakan keju lembut dari susu kambing atau susu domba. Seiring dengan perkembangannya,

Pada umumnya cheesecake dibuat dengan menggunakan cream cheese. Cheesecake biasanya dimakan sebagai hidangan penutup dan dibuat dengan mencampurkan keju yang bertekstur lembut, telur, susu, dan gula. Menurut Geary (2018) menyatakan tipe- tipe cheesecake yaitu: NewYork Cheesecake, Cheesecake Italia dibuat dengan menggunakan keju ricotta atau mascarpone, gula, vanlili, dan tepung roti. Dibandingkan dengan cheesecake Amerika, tekstur kue ini lebih kering.

Istilah dalam bahasa Jerman, cheesecake disebut dengan Käsekuchen. Biasanya, kue ini memakai keju quark. Bagian bawahnya dilapisi remah-remah biskuit, sedangkan bagian atasnya memakai buah-buahan atau kismis. Cheesecake Jerman jenis lainnya adalaah Käsesahnetorte, yaitu cheesecake yang ditambahkan krim, tapi tidak dipanggang.

Keju neufchatel merupakan bahan utama yang digunakan dalam olahan cheesecake Perancis. Teksturnya lebih ringan karena menggunakan tambahan meringue atau kocokan putih telur. Dalam bahasa Swedia, "ost" berarti kue dan "kaka" berarti keju. Sehingga mereka sering menyebutnya sebagai Ostekake atau Ostakaka. Berbeda dengan pembuatan cheesecake pada umumnya, Ostakaka dibuat dengan cara mengentalkan susu segar menggunakan enzim, yang bisa memisahkan susu terbagi menjadi bagian padat dan cair. Setelah dikentalkan, kemudian susu dipanggang.

Japanese cheesecake, Kue ini juga sering disebut dengan Japanese cotton cheesecake karena teksturnya basah, lembut dan mirip dengan kapas. Bentuknya berbeda dengan cheesecake Eropa yang cenderung berat dan creamy. Japanese chesecake lebih ringan, fluffy, dengan rasa yang tak terlalu bold. Didibandingkan dengan aroma cream cheese, Japanese cheesecake mempunyai aroma vanila dan telur yang lebih kuat.

Bahan-bahan pembuatan cheesecake adalah cream cheese, susu, telur, gula, mentega, cream of tartar, vanilla essence, dan tepung sayuran yang telah di olah, yaitu tepung buncis. Cream cheese atau yang juga dikenal dengan krim keju adalah salah satu jenis keju lunak yang memiliki tekstur mirip seperti mentega. Hal ini sejalan dengan definisi dari Gisslen (2015) cream cheese yang digunakan 
untuk membuat cheesecake adalah keju krim, soft cheese atau keju segar/fresh cheese.

Cream cheese biasanya digunakan untuk bahan olesan roti dan kue, filling cake, atau bahan utama untuk membuat cheesecake. Sebagai olesan atau filling. Dari segi kandungan gizinya, cream cheese hampir sama saja dengan keju yang lain. Namun biasanya cream cheese lebih didominasi oleh campuran lemak. Susu murni mengandung lemak, yang harus dihitung sebagai bagian dari shortening dalam adonan. Oleh karena itu, susu murni dan susu skim tidak dapat dipertukarkan dalam formula kecuali jika penyesuaian dilakukan untuk lemak. Hal ini sejalan dengan teori yang diungkapkan Gisslen (2016). Telur merupakan bahan baku yang sangat berpengaruh pada hasil akhir adonan roti atau kue.

Fungsi telur terhadap adonan dapat menambah nilai gizi, menguatkan rasa, membantu proses pengembangan produk, memperlunak, dan memperbaiki tekstur remah dalam adonan. Putih telur akan mempengaruhi volume adonan yang membesar karena dalam adonan terdapat gelembung udara yang besar dan tak beraturan. Akibatnya, adonan akan cepat turun karena jaringan terlalu lemah. Sedangkan kuning telur akan mempengarui volume adonan lebih kecil karena dalam kuning telur terdapat gelembung udara yang halus sehingga jaringan menjadi kuat tidak mudah turun.

Gula memiliki peran yang penting dalam setiap resep kue. Tanpa gula, sebuah kue akan hambar, tidak mempengaruhi dalam segi rasa, kue tampak pucat, pendek, dan padat. Dampak gula pada kue cukup beragam. Gula sebagai bahan dasar yang utama sebagai pembuat rasa, juga memiliki fungsi yang lain, yaitu sebagai penyedap, selain memiliki rasa yang manis, gula juga berfungsi sebagai karamelisasi dan pemberi warna kerak kecoklatan pada kue. Tanpa gula, kue akan terasa seperti mentah, dan tidak ada nuansa seperti adanya penambahan gula seperti karamelisasi dan tidak adanya warna kecoklatan pada kue setelah kue tersebut dipanggang. Hal ini sejalan dengan definisi dari kutipan Gisslen (2016,)

Fungsi mentega dalam pembuatan kue sebagai lemak yang menjaga agar kue lebih tahan lama, memberi aroma dan rasa khas, membuat tekstur kue menjadi empuk serta menjaga kelembaban kue dengan mengikat cairan dalam kue. Penggunaan mentega pada pembuatan cheesecake yang diteliti membuat kue lebih lentur dan lembut meskipun kue sudah dingin atau sudah menginap hal ini sesuai yang dikemukakan Gisslen (2016).

Cream of Tar Tar merupakan bahan yang ditambahkan saat mengocok putih telur dalam proses membuat kue, kue bolu, meringue atau kue-kue yang memerlukan kocokan putih telur sampai mengembang kaku. Cream of tartar mengeluarkan gas di dalam adonan sehingga akan dihasilkan volume kocokan telur yang baik, dan tentu akan menghasilkan tekstur pori-pori kue yang lebih baik terutama dalam mencapai tekstur cheesecake yang di inginkan, Gisslen (2016).

Manfaat sayuran adalah melancarakan pencernaan, sumber vitamin, mineral, gizi bagi tubuh, mencegah kanker, sumber utama serat, meningkatkan sistem imun dan meningkatkan kesehatan mata. Hal ini sejalan dengan teori yang diungkap oleh Watson (2015). Maka dari itu bagaimana sayuran bisa diolah menjadi tepung untuk menjadi salah satu komponen cheese cake yang bermanfaat bagi orang-orang yang tidak bisa mengkonsumsi gluten dan menjadi alternatif bagi orang-orang yang tidak menyukai sayuran.

Buncis memiliki kandungan gizi buncis juga sangat kaya akan serat, dimana kandungan serat ini sangat bermanfaat juga bagi tubuh kita. Serat mampu membantu untuk mengontrol kadar kolesterol serta glukosa darah dalam tubuh kita.. Pada tabel berikut di uraikan kandungan gizi pada sayuran buncis. 
Tabel 1

Komposisi Zat Gizi Sayuran Kacang Buncis Per 100gr Bahan

\begin{tabular}{ccc}
\hline No & Jenis zat gizi & Jumlah kandungan gizi \\
\hline 1 & Energi/kalori & $35 \mathrm{kal}$ \\
2 & Protein & $2,4 \mathrm{~g}$ \\
3 & Lemak & $0,2 \mathrm{~g}$ \\
4 & Karbohidrat & $7,7 \mathrm{~g}$ \\
5 & Kalsium & $6,5 \mathrm{~g}$ \\
6 & Fosfor & $4,4 \mathrm{~g}$ \\
7 & Serat & $1,2 \mathrm{~g}$ \\
8 & Besi & $1,2 \mathrm{~g}$ \\
9 & Vitamin A & $630,0 \mathrm{Sl}$ \\
10 & Vitamin B1/Thiamine & $0,08 \mathrm{mg}$ \\
11 & Vitamin B2/Riboflavin & $0,1 \mathrm{mg}$ \\
12 & Vitamin B3/Niacin & $0,7 \mathrm{mg}$ \\
13 & Vitamin C & $19,0 \mathrm{mg}$ \\
14 & Air & $89 \mathrm{~g}$ \\
\hline
\end{tabular}

Sumber: Cahyono (2013)

\section{METODE PENELITIAN}

Menurut Best \& Kahn (2010,), penelitian eksperimen merupakan penelitian yang paling dapat diandalkan keilmiahannya karena dilakukan dengan pengontrolan secara ketat terhadap variabel-variabel pengganggu di luar yang dieksperimenkan. penelitian eksperimen merupakan bentuk khusus investigasi yang digunakan untuk menentukan variabel-variabel apa saja dan bagaimana bentuk hubungan antara satu dengan yang lainnya.

Menurut konsep klasik, eksperimen merupakan penelitian untuk menentukan pengaruh variabel perlakuan terhadap variabel dampak. Borg \& Gall (2013). Metode penelitian pada dasarnya merupakan cara ilmiah untuk mendapatkan data dengan tujuan dan kegunaan tertentu. Metode penelitian yang dipakai adalah metode eksperimen. Hal ini seperti yang diungkapkan oleh Sugiyono (2014).I Penelitian dengan metode eksperimen adalah penelitian dimana datanya belum pernah ada, sehingga harus diciptakan terlebih dahulu. Hal ini sejalan dengan yang disampaikan oleh Gulo (2013).
Variabel penelitian adalah segala sesuatu yang berbentuk apa saja yang ditetapkan oleh peneliti untuk dipelajari sehingga diperoleh informasi tentang hal tersebut, kemudian ditarik kesimpulan sesuai dengan yang di tulis oleh Sugiyono (2013). Dalam hal ini memakai 1 variable yaitu $\mathrm{X} 1$ : Buncis

Populasi cheesecake dimana variable merupakan varian kategori dari setiap uji coba. Variabel ini merupakan bagian dari uji coba cheesecake tanpa menggunakan tepung terigu kemudian digantikan dengan tepung sayuran. Di dalam buku yang ditulis oleh Sukmadinata (2013) ada sepuluh langkah dalam pelaksanaan strategi penelitian dan pengembangan yaitu:

Penelitian dan pengumpulan data (research and information collecting) yang meliputi pengukuran kebutuhan, studi literatur, penelitian dalam skala kecil, dan pertimbangan dari segi nilai. Perencanaan (planning) dengan menyusun rencana penelitian yang meliputi kemampuan yang diperlukan dalam pelaksanaan penelitian, rumusan tujuan yang hendak dicapai, desain penelitian, dan kemungkinan pengujian dalam lingkup terbatas.

Pengembangan produk (develop preliminary form of product) meliputi pengembangan 
bahan pembelajaran, proses pembelajaran, dan instrument evaluasi. Merevisi hasil uji coba (main product revision) dengan memperbaiki atau menyempurnakan hasil uji coba. Uji coba lapangan (main field testing) dengan melakukan uji coba kepada panelis terlatih dibidang Bakery and pastry. Penyempurnaan produk hasil uji lapangan (operational product revision) yaitu menyempurnakan produk hasil uji lapangan. Uji pelaksanaan lapangan (operational field testing), Penyempurnaan produk akhir (final product revision) yaitu penyempurnaan yang didasarkan pada masukan dari uji pelaksanaan lapangan. Diseminasi dan implementasi (dissemination and implementation) yaitu melaporkan hasilnya dalam pertemuan profesional dan dalam jurnal.

One Shot Case Study adalah merupakan desain penelitian yang terdiri dari satu kelompok yang diberi perlakuan yang kemudian mengobservasi hasil tersebut. Hal ini tertulis pada buku karangan Sugiyono (2013). Dalam hal ini penulis menyepakati untuk melakukan uji panel hedonik dan mutu hedonik pada 25 orang panelis terlatih dibidang bakery dan pastry. Dimana para panelis diminta untuk mencoba cheesecake yang sudah dibuat kemudian memberikan nilai pada tabel penilaian yang diberikan.

Pada proses percobaan pertama untuk menemukan jenis sayuran apa yang sesuai agar dapat menggantikan tepung terigu sebagai salah satu komponen cheesecake. Pada percobaan pertama menggunakan 2 jenis sayuran pertama yaitu Kale dan Brokoli. Proses pengeringan kedua sayuran tersebut menggunakan oven deck suhu $75{ }^{\circ} \mathrm{C}$ dengan waktu yang berbeda. Dikarenakan daun kale sangat tipis maka hanya membutuhkan waktu sekitar 4-5 jam sedangkan karena brokoli membutuhkan waktu sekitar 7-8 jam lalu di haluskan dengan stick blender.

Pemanggangan cheesecake pada suhu $180^{\circ} \mathrm{C}$ selama 45 menit menggunakan tehnik au bain marie. Hasil dari penelitian pertama warna permukaan cheese cake agak kecoklatan, tekstur cheesecake masih kurang soft dan masih terlihat dan terasa tepung kedua sayuran tersebut kurang halus dan juga after taste dari vegetable cheesecake ini sangat terasa dari sayuran tersebut. Akhirnya setelah dilakukan evaluasi yang mendalam, dilakukan percobaan kembali dengan menggunakan resep yang lain, teknik baru serta alternatif jenis dan macam, sayuran lain yang bisa dijadikan alternatif.

Pada proses percobaan kedua dilakukan percobaan dengan 3 macam sayuran yaitu kembang kol, sawi dan daun mint. Dilakukan juga pencarian resep baru dan komposisi bahan yang sesuai agar memperbaiki tekstur vegetable cheesecake tersebut.

Penggantian beberapa metode dan suhu pembakaran cheesecake tersebut. Dilakukan pengeringan 3 sayuran tersebut di oven deck dengan suhu $75^{\circ} \mathrm{C}$ selama 8 jam dan ternyata sawi gagal di keringkan, sangat basah untuk di gunakan sebagai tepung sayuran. Kemudian digunakan dry mill blender bumbu untuk menghancurkan sayuran tersebut dan hasilnya sangat halus dibandingkan dengan penelitian pertama. Beberapa metode lainnya adalah mengolah cream cheese, susu dan butter dengan cara di panaskan pada kompor dan sampai tercampur halus, pada percobaan pertama hanya di campur di mixer. Hal ini menyebabkan aroma dan rasa dari cream cheese tersebut lebih keluar. Dilakukan juga pemanggangan cheesecake dengan suhu yang berbeda yaitu pertama suhu $120^{\circ} \mathrm{C}$ selama 30 menit dilanjutkan suhu $150^{\circ} \mathrm{C}$ selama 20 menit lalu suhu $100^{\circ} \mathrm{C}$ selama 40 menit menggunakan teknik au bain marie.

Hasil dari penelitian kedua warna kecoklatan cheesecake lebih baik dari sebelumnya, tetapi tekstur cheesecake lebih padat dari sebelumnya. Cheesecake terlihat lebih bantat karna akibat penurunan suhu yang drastis, walaupun tepung sayuran terlihat lebih menyatu dengan adonan dan lebih halus. Cheesecake yang menggunakan kembang kol terlihat bantat dan kurang lebih sama untuk segi rasa dengan penelitian pertama tetapi cheesecake yang menggunakan daun mint sangat terasa after taste dari daun mint tersebut sehingga agak sedikit pahit. Oleh 
karena itu diputuskan untuk tidak menggunakan kembang kol dan daun mint.

Pada proses ketiga pembuatan cheesecake, dipilih jenis sayuran lain dengan memilih sayuran golongan buah yaitu buncis. Pemanggangan sayuran ini dengan suhu $75^{\circ} \mathrm{C}$ selama 8 jam menggunakan oven deck dengan membelah dua masing-masing buncis agar lebih cepat kering. Dikurangkan juga jumlah tepung sayurannya agar tidak sepadat penelitian sebelumnya. Hasil pengeringan dari buncis ini baik dan cukup kering lalu dihaluskan dengan menggunakan dry mill blender dan di ayak agar tekstur cheesecake lebih baik.

Resep dan metode yang digunakan pada penelitian kali ini sama dengan penelitian kedua tetapi mencoba membakar cheesecake dengan suhu dan waktu yang berbeda agar mencapai warna dan tektur yang di inginkan. Pemanggangan cheesecake dengan suhu $150^{\circ} \mathrm{C}$ selama 30 menit dilanjutkan dengan suhu $120^{\circ} \mathrm{C}$ menggunakan teknik au bain marie. Hasil dari percobaan cheesecake kali ini sudah lebih baik dari sebelumnya. Warna kecoklatan sudah mencapai titik golden brown yang di inginkan dan tekstur lebih baik karna jumlah tepung sayuran yang di kurangi tetapi tekstur masih agak basah di bagian bawah dan rasa dari vegetable cheesecake ini lebih baik dari penelitian sebelumnya.

Akhirnya dilaksanakan tes panel dan mencoba melakukan penelitian selanjutnya untuk mencapai hasil vegetable cheesecake yang lebih baik. Seperti yang diungkapkan oleh Valliant \& Richard (2010,) bahwa penentuan populasi dan sampel penelitian menjadi sangat penting, karena hasil penelitian pada umumnya akan mengambil kesimpulan secara luas (generalisasi hasil penelitian).

Ketepatan dan keakuratan dalam penentuan populasi dan sampel penelitian akan memberikan bobot dan kualitas hasil penelitian. Oleh karena itu, dalam mempersiapkan desain penelitian harus benar-benar mampu menentukan populasi dan sampel secara baik yang dijabarkan sesuai uraian berikut: Populasi ditujukan kepada semua orang, kejadian dan hal-hal yang menarik bagi peneliti untuk diselediki. Hal ini juga diungkapkan oleh buku karangan Sekaran \& Bougie (2016).

Target populasi yang dipilih adalah orang yang mempunyai latar belakang di bidang bakery dan pastry. Sekaran \& Bougie (2016) menyatakan pada bukunya sampel adalah: merupakan bagian dari populasi. Terdiri dari beberapa anggota yang dipilih. Dengan kata lain, sebagian, tetapi tidak semua, elemen populasi ini membentuk sampel. Sekaran \& Bougie (2016) menyatakan dalam buku karangannya bahwa sampling process merupakan proses pemilihan jumlah yang tepat dari unsur-unsur yang tepat dari populasi, sehingga studi tentang sampel dan pemahaman tentang sifat atau karakteristiknya memungkinkan untuk mengeneralisasikan sifat atau karakteristik tersebut.

Teknik sampling yang digunakan dalam penelitian ini adalah non- probability sampling. Sekaran \& Bougie (2016) menyatakan teknik sampling dikelompokan menjadi 2 bagian yaitu probability sampling dan non-probability sampling. Probability sampling adalah unsur-unsur dalam populasi yang memiliki beberapa peluang yang diketahui, bukan nol atau kemungkinan dipilih sebagai sampel subyek. Sedangkan Non-probability sampling adalah: Unsurunsur tidak memiliki kemungkinan yang diketahui atau yang telah ditentukan sebelumnya dan dipilih sebagai subjek.

Teknik ini dilakukan karena beberapa pertimbangan. Dalam penelitian ini, keterbatasan disebabkan oleh keterbatasan waktu dan pembuatan cheesecake yang cukup kompleks sehingga membuat penelitian terbatas dalam membuat produk sehingga mempengaruhi dalam penentuan sampel. Maka dari itu, dipilih 25 responden. Objek penelitian dalam hal ini adalah Cheesecake.

Cheesecake pada umumnya menggunakan bahas dasar tepung terigu. Tetapi banyak masyarakat yang tidak bisa mengkonsumsi gluten yang terdapat didalam tepung terigu. Oleh sebab itu, diteliti cheesecake tanpa 
menggunakan tepung terigu dan digantikan dengan tepung sayuran. Subjek yang diteliti dalam penelitian ini adalah 25 panelis terlatih di bidang bakery dan pastry yang benarbenar mengenal dan memahami produk pastry dengan baik. Diteliti pula kesukaan mereka dan dijadikan sebagai masukanmasukan agar cheesecake menjadi lebih baik.

\section{Teknik Pengumpulan Data}

Salah satu komponen yang penting dalam penelitian adalah proses peneliti dalam pengumpulan data. Kesalahan yang dilakukan dalam proses pengumpulan data akan membuat proses analisis menjadi sulit. Selain itu hasil dan kesimpulan yang akan didapat pun akan menjadi rancu apabila pengumpulan data dilakukan tidak dengan benar. Masing-masing penelitian memiliki proses pengumpulan data yang berbeda, tergantung dari jenis penelitian yang hendak dibuat oleh peneliti.

Pengumpulan data kualitatif pastinya akan berbeda dengan pengumpulan data kuantitatif. Pengumpulan data statistik juga tidak bisa disamakan dengan pengumpulan data analisis, hal ini seperti yang diungkapkan oleh Salant (2011). Sekaran \& Bougie (2016) mengatakan didalam bukunya bahwa data primer adalah kumpulan data yang didapatkan dari sumber asli yang sesuai dengan tujuan penelitiannya.

Peneliti menggunakan data primer sebagai salah satu acuan dalam penelitiannya. Kuisioner pada penelitian ini terdiri dari inovasi cheesecake kacang buncis dengan empat aspek yaitu aspek rasa, warna, tekstur dan aroma. Responden dapat menilai setiap aspek bantuan skala dan memberi tanggapan pribadinya pada kolom yang sudah disediakan.

Menyusun instrumen merupakan langkah penting dalam pola prosedur penelitian. Instrumen berfungsi sebagai alat bantu dalam mengumpulkan data yang diperlukan. Bentuk instrumen berkaitan dengan metode pengumpulan data, misal metode wawancara yang instrumennya pedoman wawancara. Metode angket atau kuesioner, instrumennya berupa angket atau kuesioner. Metode tes, instrumennya adalah soal tes, tetapi metode observasi, instrumennya bernama chek-list.

Menyusun instrumen pada dasarnya adalah menyusun alat evaluasi, karena mengevaluasi adalah memperoleh data tentang sesuatu yang diteliti, dan hasil yang diperoleh dapat diukur dengan menggunakan standar yang telah ditentukan sebelumnya oleh peneliti. Dalam hal ini terdapat dua macam alat evaluasi yang dapat dikembangkan menjadi instrumen penelitian, yaitu tes dan non-tes. Hal ini diungkapkan oleh Millan \& Schumacher (2010).

Sejalan dengan hal yang dikatakan oleh Sugiono (2013) penelitian eksperimen dapat dikatakan sebagai metode penelitian yang digunakan untuk mencari pengaruh perlakuan tertentu terhadap yang lain dalam kondisi yang terkendalikan. Dengan kata lain bahwa penelitian eksperimen adalah bagian dari penelitian kuantitatif yang terdapat variabel sehingga dapat ditemukan sebab akibat yang sengaja ditimbulkan dari variabel tersebut.

Definisi lain menyatakan bahwa penelitian eksperimen adalah penelitian yang dilakukan terhadap variabel yang data-datanya belum ada sehingga perlu dilakukan proses manipulasi melalui pemberian perlakuan tertentu. Hal ini juga diungkapkan oleh Siregar (2013) menyatakan penelitian eksperimen merupakan penelitian yang dilakukan untuk memprediksi suatu fenomena, dengan demikian, penelitian eksperimental adalah penelitian yang dilakukan dengan mengadakan manipulasi terhadap objek penelitian yaitu cheesecake.

Manipulasi disini merupakan inovasi baru mengenai bahan cheesecake yang pada umumnya menggunakan tepung terigu di buat dengan substitusi golongan sayuran buah yaitu kacang buncis.

Menurut Stone, Bleibaum, dan Thomas (2013), uji organoleptic adalah : Penelitian dilakukan berdasarkan rasa, warna, testur dan aroma terhadap pengujian yang didasarkan pada proses penginderaan. Maka dari itu pengujian organoleptik mempunyai peranan penting dalam penerapan mutu. Pengujian organoleptik dapat memberikan indikasi 
kebusukan, kemunduran mutu dan kerusakan lainnya dari produk. Oleh sebab itu, penelitian dilakukan dengan penyebaran inovasi cheesecake dengan kacang buncis sebagai pengganti tepung.

Uji Hedonik dikutip di dalam buku karangan Setyaningsih, Dwi, Apriyantono \& Sari (2014) adalah upaya untuk mengetahui respon panelis terhadap sifat mutu yang umum. Uji hedonik memberikan pernyataan kesan tentang baik atau buruknya suatu produk. Uji ini dilakukan untuk mengetahui tingkat kesukaan produk yang satu dengan produk yang lain secara langsung. Uji ini dapat diaplikasikan saat pengembangan produk atau pembanding produk.

Dalam Penelitian ini, dilakukan uji hedonik untuk mengetahui tingkat kesukaan responden terhadap cheesecake kacang buncis menggunakan skala hedonik dengan 5 skala numerik yaitu angka 5 untuk sangat suka, angka 4 untuk suka, angka 3 untuk agak suka, angka 2 untuk agak tidak suka dan angka 1 untuk tidak suka hal ini dikemukanan oleh Saludung (2018). Dengan skala tersebut maka dapat membantu untuk mengetahui tingkat kesukaan cheesecake kacang buncis oleh responden.

Skala hedonik dapat digunakan sesuai kebutuhan dari peneliti dimulai dari sangat suka, suka, agak suka, agak tidak suka, tidak suka. Kesukaan seseorang terhadap cheesecake kacang buncis merupakan hal penting dalam penelitian ini karena dari hal tersebut dapat memberikan penilaian dan penentuan dalam hasil penelitian.

Dalam Penelitian ini, dilakukan juga uji mutu hedonik untuk mengetahui tingkat kualitas cheese cake kacang buncis menurut panelis dengan menggunakan skala mutu hedonik predikat sangat baik dengan numerik yaitu angka 5, predikat baik dengan angka 4, predikat agak baik dengan angka 3, predikat agak tidak baik dengan angka 2 dan predikat tidak baik dengan angka 1 dikemukakan oleh Saludung (2018).

Menurut Sarastani (2014). Uji hedonik dilakukan dengan cara panelis diminta tanggapan pribadinya tentang kesukaan atau ketidaksukaannya terhadap komoditi yang dinilai, bahkan tanggapan dengan tingkatan kesukaan atau tingkatan ketidak sukaannya dalam bentuk skala hedonik. Sedangkan untuk Uji mutu hedonik merupakan kesan mutu hedonik lebih spesifik, yaitu tidak sekedar suka atau tidak suka tetapi bersifat kesan spesifik dari sifat khas produknya . Maka dari itu dilakukan uji mutu hedonik untuk mengetahui kualitas produk cheesecake kacang buncis yang telah di teliti.

\section{HASIL DAN PEMBAHASAN}

Setelah data-data yang perlukan terkumpul, maka langkah selanjutnya dalam penelitian ekspermen ini, teknik analisis data dilakukan dengan cara menggunakan analisis sensori dan rata-rata hitung seperti yang dijabarkan di berikut ini: Analisis Sensori yaitu mengidentifikasi dan mendiskripsikan aspek rasa, warna, aroma dan tekstur dari kacang buncis sebagai bahan substitusi tepung terigu sedangakan Rata-rata Hitung dalam pengolahan data dari uji hedonik dan mutu hedonik dengan menggunakan rumus sebagai berikut: Total nilai per indikator di jumlahkan : total panelis Sehingga peneliti akan mendapatkan hasil nilai rata-rata per aspek seperti rasa, warna, aroma, tekstur serta rata-rata secara keseluruhan terhadap inovasi vegetables cheesecake.

Dibawah ini merupakan table olahan data uji coba panelis dengan teknik uji hedonik dan mutu hedonik pada cheesecake kacang buncis. Dalam kategori cheesecake dengan varian yang diuji coba yaitu cheesecake dengan menggunakan kacang buncis sebagai pengganti tepung terigu. 
Tabel 2

Uji Hedonik Cheesecake Menggunakan Sayuran Buncis

\begin{tabular}{|c|c|c|c|c|c|c|c|}
\hline \multicolumn{8}{|c|}{ Buncis } \\
\hline \multicolumn{4}{|c|}{ Rasa } & \multicolumn{4}{|c|}{ Aroma } \\
\hline $\begin{array}{c}\text { Buncis } \\
\mathrm{R}\end{array}$ & Total & Mean & $\begin{array}{l}\% \text { of } \\
\text { Total N }\end{array}$ & Buncis A & Total & Mean & $\begin{array}{l}\% \text { of } \\
\text { Total N }\end{array}$ \\
\hline 1 & 0 & & $0 \%$ & 1 & 0 & & $0 \%$ \\
\hline 2 & 0 & & $0 \%$ & 2 & 0 & & $0 \%$ \\
\hline 3 & 3 & 4,24 & $12 \%$ & 3 & 5 & 4,08 & $20 \%$ \\
\hline 4 & 13 & & $52 \%$ & 4 & 13 & & $52 \%$ \\
\hline 5 & 9 & & $36 \%$ & 5 & 7 & & $28 \%$ \\
\hline Total & 25 & & $100 \%$ & Total & 25 & & $100 \%$ \\
\hline
\end{tabular}

Sumber Olahan Data

Tabel di atas menyatakan bahwa aspek rasa pada cheesecake dengan kacang buncis sebagai pengganti tepung terigu mendapatkan tingkat kesukaan pada skala nilai 4 (suka) dengan nilai persentase $52 \%$. Faktor-faktor yang mempengaruhi hal tersebut dikarenakan rasa cheese cake dengan bahan kacang buncis ini natural dan sesuai dengan rasa cheese cake pada umumnya tanpa meninggalkan after taste yang mengganggu sehingga bisa diterima dengan baik. Dari aspek aroma cheesecake kacang buncis ini mendapatkan tingkat kesukaan pada skala nilai 4 (suka) dengan memperoleh nilai persentase $52 \%$ sehingga dapat dikatakan bahwa aroma cheesecake dengan bahan kacang buncis adalah perpaduan yang serasi dengan bahan-bahan lain yang digunakan dalam membuat cheesecake tersebut sehingga menghasilkan aroma yang bisa diterima dengan tingkat kesukaan yang tinggi.

Tabel 3

Uji Hedonik Cheesecake Menggunakan Sayuran Buncis

\begin{tabular}{|c|c|c|c|c|c|c|c|}
\hline \multicolumn{4}{|c|}{ Warna } & \multicolumn{4}{|c|}{ Tekstur } \\
\hline Buncis W & Total & Mean & $\begin{array}{c}\% \text { of } \\
\text { Total } \mathrm{N}\end{array}$ & Buncis $\mathrm{T}$ & Total & Mean & $\begin{array}{c}\% \text { of } \\
\text { Total N }\end{array}$ \\
\hline 1 & 0 & \multirow{5}{*}{3,84} & $0 \%$ & 1 & 0 & \multirow{5}{*}{4,04} & $0 \%$ \\
\hline 2 & 0 & & $0 \%$ & 2 & 0 & & $0 \%$ \\
\hline 3 & 7 & & $28 \%$ & 3 & 6 & & $24 \%$ \\
\hline 4 & 15 & & $60 \%$ & 4 & 12 & & $48 \%$ \\
\hline 5 & 3 & & $12 \%$ & 5 & 7 & & $28 \%$ \\
\hline Total & 25 & & $100 \%$ & Total & 25 & & $100 \%$ \\
\hline
\end{tabular}

Sumber Olahan Data

Berdasarkan tabel di atas dinyatakan bahwa dari aspek warna cheesecake kacang buncis pada skala 4 (suka) dengan nilai persentase buncis $60 \%$, Dalam pembuatan cheesecake kacang buncis ini tidak menggunakan pewarna buatan sehingga kacang buncis ini bisa digunakan sebagai pengganti fungsi tepung dan memberikan manfaat sebagai pewarna alami. Dari aspek tekstur cheesecake kacang buncis pada skala nilai 4 (suka) dengan memperoleh nilai persentase buncis $48 \%$, pencapaian skala tersebut dikarenakan kacang buncis mampu menghasilkan tekstur yang baik dengan terlihat rongga yang bagus dari cheesecake dapat mengembang dengan sempurna namun tekstur buncis agak sedikit basah. 
Tabel 4

Uji Mutu Hedonik Cheesecake Menggunakan Sayuran Buncis

\begin{tabular}{|c|c|c|c|c|c|c|c|}
\hline \multicolumn{8}{|c|}{ Buncis } \\
\hline \multicolumn{4}{|c|}{ Rasa } & \multicolumn{4}{|c|}{ Aroma } \\
\hline $\begin{array}{c}\text { Buncis } \\
\mathrm{R}\end{array}$ & Total & Mean & $\begin{array}{l}\% \text { of } \\
\text { Total N }\end{array}$ & Buncis A & Total & Mean & $\begin{array}{l}\% \text { of } \\
\text { Total N }\end{array}$ \\
\hline 1 & 0 & & $0 \%$ & 1 & 0 & & \\
\hline 2 & 0 & & $0 \%$ & 2 & 0 & & 0 \\
\hline 3 & 2 & 4,28 & $8 \%$ & 3 & 5 & 4 & $20 \%$ \\
\hline 4 & 14 & & $56 \%$ & 4 & 15 & & $60 \%$ \\
\hline 5 & 9 & & $36 \%$ & 5 & 5 & & $20 \%$ \\
\hline Total & 25 & & $100 \%$ & Total & 25 & & $100 \%$ \\
\hline
\end{tabular}

Sumber Olahan Data

Berdasarkan tabel di atas tingkat kualitas rasa buncis mencapai skala nilai 4 (baik) dengan memperoleh nilai persentase $56 \%$ sedangkan aspek aroma cheesecake kacang buncis dengan skala nilai tertinggi di angka 4 (baik) dengan persentase buncis $60 \%$. Faktor-faktor yang mempengaruhi hal tersebut dikarenakan sayuran buncis mengeluarkan aroma yang paling baik dengan aroma khas buncis yang wangi dan tidak mengeluarkan aroma sayuran yang kuat dan sesuai untuk menjadi aroma cheesecake.

Tabel 5

Uji Mutu Hedonik Cheesecake Menggunakan Sayuran Buncis

\begin{tabular}{|c|c|c|c|c|c|c|c|}
\hline \multicolumn{4}{|c|}{ Warna } & \multicolumn{4}{|c|}{ Tekstur } \\
\hline Buncis W & Total & Mean & $\begin{array}{c}\% \text { of } \\
\text { Total } \mathrm{N}\end{array}$ & Buncis $\mathrm{T}$ & Total & Mean & $\begin{array}{c}\% \text { of } \\
\text { Total } \mathrm{N}\end{array}$ \\
\hline 1 & 0 & & $0 \%$ & 1 & 0 & & $0 \%$ \\
\hline 2 & 0 & & $0 \%$ & 2 & 0 & & $0 \%$ \\
\hline 3 & 2 & 3,8 & $8 \%$ & 3 & 6 & 4,08 & $24 \%$ \\
\hline 4 & 14 & & $56 \%$ & 4 & 11 & & $44 \%$ \\
\hline 5 & 9 & & $36 \%$ & 5 & 5 & & $20 \%$ \\
\hline Total & 25 & & $100 \%$ & Total & 25 & & $100 \%$ \\
\hline
\end{tabular}

Berdasarkan tabel di atas menyatakan bahwa dari aspek warna jenis vegetable cheesecake tersebut dinyatakan bahwa tingkat kualitas warna dari sayuran tertinggi terdapat pada skala nilai 4 (baik) dengan nilai persentase buncis 56\%, Pencapaian skala nilai uji mutu hedonic baik karena buncis menghasilkan warna kehijauan yang membuat tampilan cheesecake lebih menarik. Sedangkan dari aspek aspek tekstur pada skala nilai 4 (baik) dengan memperoleh nilai persentase buncis $44 \%$, Hal yang mempengaruhi pencapaian tekstur yang baik dengan terlihat rongga yang bagus dari cheesecake kacang buncis ini meskipun agak lembab (moist).

\section{KESIMPULAN}

Penelitian ini bertujuan untuk memperkenalkan kepada masyarakat tentang inovasi baru cheesecake tanpa menggunakan tepung terigu dan digantikan dengan tepung sayuran dari kacang buncis.

Proses pengeringan sayuran kacang buncis sangat mempengaruhi rasa dan tekstur cheesecake yang akan dibuat oleh karena itu perlu prosedur tertentu untuk menghasilkan tepung kacang buncis yang terbaik sebagai bahan pembuat cheesecake.

Proses penghalusan sayuran yang kering mempengaruhi tekstur pada cheesecake demikian pula jenis sayuran mempengaruhi tekstur cheesecake. Proses teknik memanggang kue sangat mempengaruhi hasil. Proses memanggang kue harus pada suhu $140^{\circ} \mathrm{C}$ dan dengan teknik au bain marie, setelah lewat dari 4 hari cheesecake yang disimpan di suhu ruangan sudah tidak layak konsumsi, sedangkan jika disimpan 
didalam chiller akan tahan selama kurang lebih 1-2 minggu.

\section{UCAPAN TERIMA KASIH}

Saya mengucapkan banyak terima kasih kepada LPPM UPH yang telah memfasilitasi penelitian ini dan tentunya semua pihak yang telah membantu dalam proses penulisan artikel ini, kiranya artikel ini bisa berguna bagi yang membacanya.

\section{REFERENSI}

Best, J. W. \& Kahn, J. V. 2010. Research in education, ( $5^{\text {th }}$ ed.). New Delhi: Prentice-Hall of India Pvt. Ltd.

Borg \& Gall 2013. Educational Research: An Introduction, $\left(4^{\text {th }}\right.$ ed.). New York: Longman.

Beranbaum, R. L. 2013. The Cake Bible, $\left(8^{\text {th }}\right.$ ed.). New York: William Morrow Cookbooks.

Cahyono, B. 2013. Teknik Budi Daya \& Usaha Tani. Yogyakarta: Kanisius.

Geary, G. 2017. The Cheesecake Bible. United Kingdom: Wiley.

Gisslen, W. 2015. Professional Baking $\left(7^{\text {th }}\right.$ ed.). United Kingdom: Wiley.

Gisslen, W. 2016. Professional Baking ( $8^{\text {th }}$ ed.). United Kingdom: Wiley.

Gulo. 2013. Metodologi Penelitian. Jakarta : Grasindo

Henderson, G. 2016. The Ultimate Ketogenic Cheesecake. Amerika: Create Independent.

Kementrian Perindustrian. Perbandingan Kumulatif Pertumbuhan Industri NonMigas.
Millan, J. H. \& Schumacher, S. 2010 Research in Education: Conceptual Introduction. New York: Longman.

Salant, P. 2011. How to Conduct Your Own Survey. New York: Wiley.

Saludung, J. 2018. Pengembangan dan Penerapan Model Berbagai Jenis Makanan Kue Berbasis Lokal dan Ecopreneurship. Makassar.

Sarastani, D. 2012. Penuntun Praktikum Analisis Organoleptik. Bogor: Program Diploma Institut Pertanian Bogor.

Sekaran, U. \& Bougie, R. 2016. Research Methods for Business. United Kingdom: Wiley.

Sekaran, U. \& Bougie, R. 2013. Research Methods for Business. United Kingdom: Wiley.

Siregar. 2013. Statistik Parametrik untuk Penelitian Kuantitatif (Cetakan ke-1). Jakarta: Bumi Aksara.

Setyaningsih, Dwi, Apriyantono, A., \& Sari, M. P. 2010. Analisis Sensori untuk Industri Pangan \& Argo. Bogor: IPB Press.

Stone, Bleibaum, \& Thomas 2012. Sensory Evaluation Practices: Food Science and Technology, (4 ${ }^{\text {th }}$ Ed.). London: Academic Press.

Sugiono. 2013. Metode Penelitian Kuantitatif Kualitatif dan $R \& D$. Bandung: Alfabeta.

Sugiono 2014. Metode Penelitian Pendidikan Pendekatan Kuantitatif, Kualitatif dan $R \& D$. Bandung: Alfabeta.

Sukmadinata, N. S. 2013. Metode Penelitian Pendidikan. Bandung: Remaja Rosadakarya. 
Valliant, J. \& Richard, B. 2010. Finite

Population Sampling and Inference: A

Prediction Approach. London: Wiley.

Watson, R. R. (2015). Vegetables, Fruits, and Herbs in Health Promotion. Amerika: Academic Press.

Wilderjans, E., Luyts, A., Brijs, K., \& Delcour, J. A. 2013. Ingredient functionality in batter type cake making. 